\title{
Freedom of information center
}

Whereas the University of Missouri has expressed its interest and intent in establishing a permanent Freedom of Information Center for the purpose of advancing the right of the people to know and to be informed through all means of communication, printed, oral, and visual,

And whereas the University has sought the advice and counsel of representatives of all newsgathering media at a meeting at the University on March I3-1.7, 1958 .

Now therefore be it resolved by the undersigned assembled representatives of newsgathering media, following thorough exploration, that we commend and endorse the concept of establishing a Freedom of Information Center at the School of Journalism and pledge to this project our full support, endorsement and assistance in developing and maintaining the Center's objectives, values and programs.

Thus read the resolution adopted by the group attending a two-day seminar at the University. The seminar resulted from conferences of the Freedom of Information Committee of the National Editorial Association at the NEA's annual meeting in Chicago in October, 1957 .

Participating in the seminar were members of the following organizations: National Editorial Association, National Press Photographers' Association, National Association of Broadcasters, Inland Press Association, NBC News (Chicago), Missouri Press Association, Newspaper Managers Association, CBSTV News (New York), Sigma Delta Chi, Associated Press Managing Editors, and Southern Newspaper Editors Association.

Representing NEA at the seminar were Lowell Jessen, Livermore, Calif., president; Paul C. Smith, Rock Rapids, Ia., director; Hugh Boyd, New Brunswick, N. J.; Guy Easterly, LaFollette, Tenn.; and Ware Edgar, Knox, Ind. Others attending included Dick Applegate, NBC News, Chicago; Howard Bell, National Association of Broadcasters, Washington, D. C.; William Bray, Missouri Press Association; Joseph Costa, King Features, New York; Arthur F. Duncan, Kansas City Star; Coleman Harwell, Nashville Tennessean; Malcolm Johnson, CBS Television News, New York; Robert McCandless, Lindsay-Schaub Newspapers, Urbana-Champaign, Ill.; Robert M. White, Mexico (Mo.) Daily Ledger; and Arthur L. Witman, St. Louis Post-Dispatch.

Moderating the sessions were Journalism Dean Earl F. English and Professor Paul L. Fisher.

These planners attended seminar at the University. They are, from left: Fisher, Harwell, Costa, Boyd, Duncan (back of Boyd), Bell, English, McCandless (back of English),

Lambert, Montague, Millis (in front), Edgar, Smith; (small group at right, front row:) Easterly, White, Witman, Jessen, Applegate, Johnson.

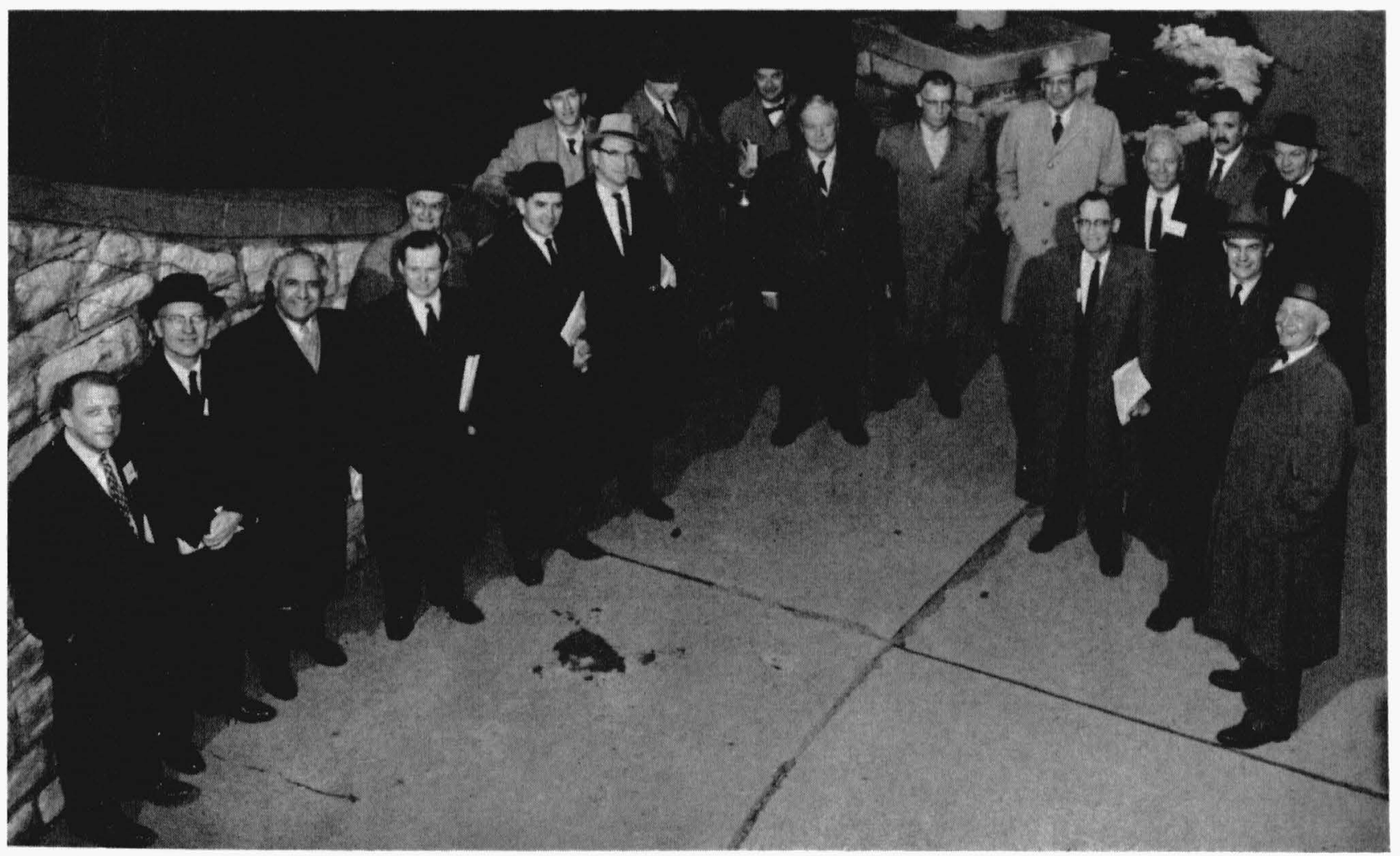

